\title{
PReS-FINAL-2069: T cells secreting granulocyte- macrophage colony stimulating factor (GM-CSF) within the inflammed joint originate from an "EX-Th17" population
}

\author{
K Nistala1*, C Piper ${ }^{1}$, A Pesenacker ${ }^{2}$, D Bending ${ }^{2}$, B Thirugnanabalan², L Wedderburn² \\ From 20th Pediatric Rheumatology European Society (PReS) Congress \\ Ljubljana, Slovenia. 25-29 September 2013
}

\section{Introduction}

Since 2003, the established paradigm of $\mathrm{T}$ cell immunology has defined interleukin (IL)-17 as a dominant Th17 cell derived cytokine driving autoimmune disease. Recent murine studies have challenged this, identifying GM-CSF as a Th17 related cytokine necessary and sufficient for the induction of autoimmunity. The origin of GM-CSF+ T cells and their relationship with IL-17 secreting cells is unclear in human autoimmune disease. Trials of biologic agents targeting the GM-CSF pathway show promise in rheumatoid arthritis, so it is important to establish if GM-CSF contributes to the inflammatory environment of the arthritic joint in Juvenile Idiopathic Arthritis (JIA).

\section{Objectives}

To analyse T cell GM-CSF production in the JIA joint and investigate the origin of GM-CSF+ T cells by testing for co-expression of the Th17 marker CD161 and modelling the plasticity of Th17 cells towards a GM-CSF phenotype in vitro.

\section{Methods}

Peripheral blood mononuclear cells (PBMC) and synovial fluid mononuclear cells (SFMC) from 17 patients with JIA were stimulated with PMA and ionomycin in the presence of Brefeldin A and analysed for IL-17, interferon gamma (ifn $\gamma$ ), GM-CSF and CD161 expression by flow cytometry. In some experiments Th17 cells

${ }^{1}$ Centre for Rheumatology, Division of Medicine, University College London, London, UK

Full list of author information is available at the end of the article were purified from healthy donor PBMC using a cytokine capture assay and upregulation of GM-CSF was examined after culture, in the presence of IL- 12 .

\section{Results}

SFMC from patients with JIA were enriched for GMCSF-secreting CD4 $\mathrm{T}$ cells, compared to matched PBMC $(21 \%$ vs $1.7 \%$ of CD 4 T cells, $\mathrm{p}=0.0012)$. The enrichment was most marked within the synovial CD161+ Th1 cell compartment. Following culture in the presence of IL-12, purified Th17 cells preferentially upregulated GM-CSF compared to IL-17-CD4 T cells (62\% vs $35 \%$ of CD4 $\mathrm{T}$ cells).

\section{Conclusion}

GM-CSF secreting $\mathrm{T}$ cells are enriched within the JIA joint. Our data shows for the first time that synovial GM-CSF+ T cells demonstrate a phenotype previously associated with ex-Th17 cells, namely IL-17-ifn $\gamma+$ CD161 + . We propose that synovial Th17 cells may drive ongoing local inflammation by undergoing plasticity towards a GM-CSF expressing phenotype in response to elevated synovial IL-12.

\section{Disclosure of interest}

None declared.

\section{Authors' details}

${ }^{1}$ Centre for Rheumatology, Division of Medicine, University College London, London, UK. ${ }^{2}$ Rheumatology Unit, UCL Institute of Child Health, London, UK. 
- Convenient online submission

- Thorough peer review

- No space constraints or color figure charges

- Immediate publication on acceptance

- Inclusion in PubMed, CAS, Scopus and Google Scholar

- Research which is freely available for redistribution 